\title{
Evaluation of Customer Service Quality
}

\author{
Ihor Cherniavskyi \\ $\mathrm{PhD}$, Head of the branch bank, PJSC CB "PrivatBank", Ukraine
}

\section{Khawla S. Abuwande}

General Manager, Office Secretary, Ministry of Foreign Affairs, Amman, Jordan

\begin{abstract}
The article proposes an approach to evaluating the quality of customer service based on a system of criteria of reliability, reactivity, competence and empathy of personnel, organization of the process of providing services. The calculations of this approach are demonstrated on the example of banks. In the process of research we have used the following methods of scientific research: factor analysis, main component method, statistical observation.
\end{abstract}

Keywords: customer service quality, performance evaluation, factor analysis.

JEL Classification: C40, G19, G21.

(C) The Authors, 2017. This article is published with open access at ARMG Publishing.

\section{Introduction}

An important task that faces the management of any company is to evaluate the quality of service provision to its customers. That is what makes the image of the company and determines its competitive position in the market of services. It is based on the quality of service provision that customers make decisions on how to use one or another service, and on choosing a company as a whole.

Fundamental principles for evaluating the quality of customer service are laid down in the research papers by F. Arnaboldi, A. N. Berger, R. DeYoung, T. M. Zverkova, P. Claeys, A. Cohen, N. Corrocher, M. J. Mazzeo, T. Hannah, B. V. Hirtle and others. In this study we relied on a scientific approach to the evaluation of service quality, developed by J.Titko, T. Lace, K. Kozlovskis (Titko, 2013).

\section{Methodology and results of research}

Currently, there are a number of scientific and methodological approaches to evaluating the quality of customer service. One of the most well-known and widely used tools for evaluating the quality of service provision is the SERVQUAL model proposed by A. Parasuraman, V. Tsiitmal and L. Berry in 1988 in the paper (Parasuraman, 1988).

According to the SERVQUAL model, the quality of services is evaluated in five main dimensions:

1) Material - physical environment of the point of sale;

2) Reliability - ability to fulfill obligations to customers;

3) Feedback - establishing friendly, open relationships with customers;

4) Security (guaranty, competence) - availability of the necessary knowledge and skills;

5) Empathy - understanding the needs of customers, their individual requests.

The emphasis is on the fact that the above-mentioned criteria, as well as a number of factors (in particular, recommendations of friends, needs of individual clients, previous experience of interaction with this company or competitors, external communications) affect the nature of perceiving the quality of service and accordingly determine customer loyalty in the future.

As can be seen from Figure 1, this model takes into account the non-compliance of customer expectations with the real quality of service they have received. 


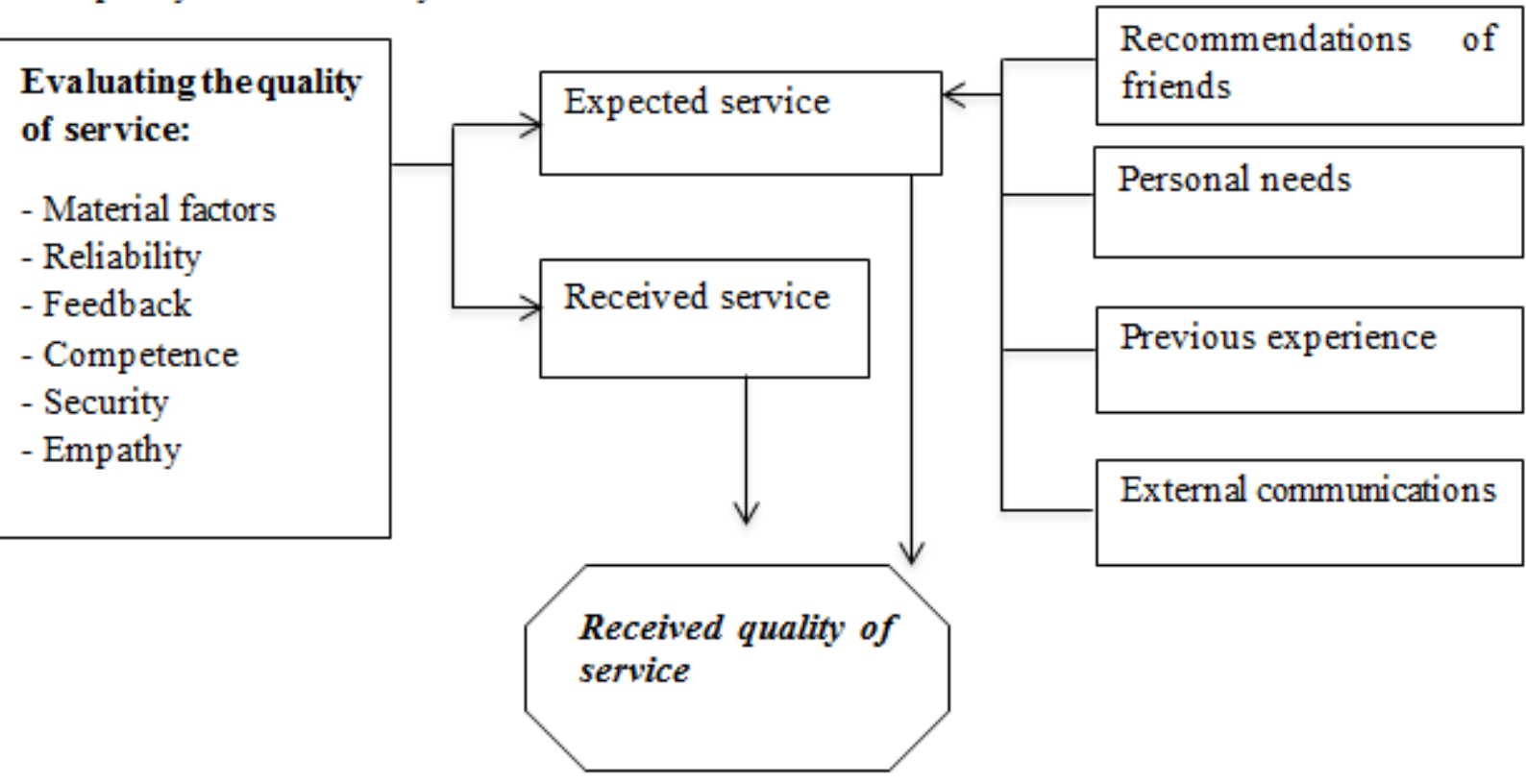

Figure 1. SERVQUAL service quality model

A SERVQUAL survey allows to identify "tight spots" in customer service as well as priority characteristics for customers to evaluate the service quality, to assess their actual level for the further improvement of the performance and customer loyalty.

The analysis of the research of modern scientific approaches to the evaluation of the quality of customer service allowed to form the following list of significant factors, according to which the assessment of the company's staff work should be conducted:

1. Appearance of employees (cleanliness, pleasant appearance, business dress code, presence of badge with the name of the employee).

2. Presence of informational handouts concerning the basic services provided by the company.

3. The personnel performs obligations to clients accurately and reliably.

4. Timely fulfillment of obligations by the company's personnel to the client.

5. The company's personnel is open to solving customer problems and is also interested in it.

6. Initiative staff of the department (offer related services that may be useful for a particular client).

7. Reliable company reputation.

8. Customers are not forced to wait for a specific service for a long period due to queues, etc.

9. A polite attitude of staff towards clients, goodwill.

10. High level of knowledge about the range of services, features of their provision (personnel is always able to answer customer's questions).

11.Individual approach to the client on the part of the staff of the company.

12. The priority of the staff is the client's interests.

13. Readiness of the personnel to correct mistakes before the client.

14. Availability of an effective feedback system for appeals, complaints and proposals.

15. Atmosphere at the company (pleasant design, cleanliness, silence in the office).

Having determined the criteria for evaluation, it is necessary to determine the methods of collecting information and the method of carrying out calculations aimed at assessing the quality of service.

Thus, the method of collecting information may be a questionnaire for the company's customers who form the sample.

Appendix A provides a questionnaire according to which we conducted a survey on customer service quality. It includes 15 evaluation criteria on which the perception of the company by customers is based.

The criteria are chosen based on empirical studies, consumer preferences analysis as well as SERVQUAL methodology.

Each criterion was proposed to be evaluated by the respondet in two dimensions: 
1) degree of its importance to the client,

2) degree of compliance with the criterion in the company where the survey was conducted.

The evaluation of each criterion by respondents was proposed to conduct on the Likert scale on the degree of agreement from 1 to 7 points, the maximum value corresponds to the option "fully agree", and the minimum value is 1 - "completely disagree".

The advantage of this method is the simplicity of perception. In addition, the optimal number of options for evaluating statements in questionnaires is 7, exceeding this value causes difficulties in determining the customers' point of view, which motivates them to choose responses by chance. Avoiding this allows to increase the level of representativeness of the study.

We conducted a customer survey on the example of three branches of the Bank PJSC CB "PrivatBank" as the largest bank in Ukraine. Respondents are retail clients of the listed departments selected during June-October 2016. As a whole, 160 questionnaires were analyzed, namely: 50 questionnaires of the branch I, 50 questionnaires of the branch II, 60 Questionnaires of the branch III. It is permissible and sufficient for further research.

Thus, according to the methodology of Nunally and Bernstein the minimum ratio of the number of respondents to the quality evaluation criteria is 10:1. In this case, this ratio is almost 11:1 (160 respondents to 15 questions in the questionnaire), which allows to suggest the representativeness of the data obtained as a result of the survey.

Stage 1. Evaluating the internal consistency of the criteria characterizing the quality of customer service by the company's employees.

An important stage in conducting research based on surveys is the evaluation of the link between each component of the test with the overall result, that is, finding out to what extent each element contradicts with others, and also allows you to evaluate each of the characteristics addressed by this survey. The representativeness of the results is ensured by the internal consistency of the test.

The evaluation is proposed to be made based on the calculation of the Cronbach's $\alpha$ coefficient, which is commonly used in economics when making surveys and checking the reliability of their results.

$\alpha_{s t}=\frac{N * \bar{r}}{1+(N-1) * \bar{r}}$

where:

$\mathrm{N}$ - number of indicators (quality assessment criteria) that were used for the survey;

$\bar{r}-$ average coefficient of correlation between components.

So, the Cronbach's Alpha can take values from 1 to - $\infty$, and only the positive values of the coefficient are interpreted during the analysis. The greater the value obtained by Cronbach's Alpha, the higher the level of internal consistency of indicators (Table 1).

Table 1. Levels of internal consistency of criteria for evaluating the quality of customer service by employees of the branch bank, depending on the level of Cronbach's Alpha (George et al., 2003)

\begin{tabular}{|c|c|}
\hline Value of Cronbach's Alpha & Level of internal consistency \\
\hline$\alpha \geq 0.9$ & Very good \\
\hline $0.9>\alpha \geq 0.8$ & Good \\
\hline $0.8>\alpha \geq 0.7$ & Permissible \\
\hline $0.7>\alpha \geq 0.6$ & Questionable \\
\hline $0.6>\alpha \geq 0.5$ & Bad \\
\hline $0.5<\alpha$ & Inadmissible \\
\hline
\end{tabular}

Using the module to calculate the Cronbach's Alpha criterion embedded in the SPSS (Statistical Package for the Social Sciences), we will determine the level of internal consistency of the criteria selected for the evaluation of the quality of service of the company.

Thus, the total value of Cronbach's Alpha for the whole set of criteria is 0.967 , which is a very good result (see Table 1) and indicates the consistency of the selected factors by $96 \%$. 
Table 2 shows the values that Cronbach's Alpha will take in the case of exclusion from the sample of each criterion. Note that the limit value of this coefficient, at which it is supposed reliable, is considered to be 0.7 (Funtowicz et al., 1990).

As the data in Table 2 show, the obtained value of $\alpha$ can no longer be maximized by removing one of the 15 criteria, since Cronbach's Alphas when removing any of them have a lower value than the aggregative index according to sample.

In order to carry out a more detailed analysis of the internal consistency of the analyzed criteria of customer service quality, we divide them into 5 groups, modified on the basis of the SERVQUAL quality evaluation methodology:

1) Organizational environment (location, equipment, information materials on basic services, offers, shares);

2) Reliability (degree of consistency and reliability of service provision to customers);

3) Personnel reactivity (responsiveness, willingness to provide assistance to the customer, promptness of assistance);

4) Competence of the personnel (knowledge of the employees of the branch of their business, availability of relevant skills);

5) Empathy of the staff (presence of compassion, desire to solve the customer's problems).

Table 2. The value of Cronbach's Alpha when removing the separate criterion for evaluating the quality of customer service from the sample

\begin{tabular}{|c|c|c|c|c|}
\hline No. & $\begin{array}{l}\text { The criterion for evaluating the quality of service by the branch } \\
\text { bank }\end{array}$ & $\begin{array}{l}\text { Designation of } \\
\text { the criterion in } \\
\text { the SPSS pro- } \\
\text { gramme }\end{array}$ & $\begin{array}{l}\text { Total } \\
\text { correlation } \\
\quad \text { of } \\
\text { correlated } \\
\text { criteria } \\
\end{array}$ & $\begin{array}{l}\text { The value of } \\
\text { Cronbach's Alpha } \\
\text { while removing } \\
\text { the criterion from } \\
\text { the sample }\end{array}$ \\
\hline 1. & $\begin{array}{l}\text { Appearance of the employees (cleanliness, pleasant appearance, } \\
\text { business dress code, availability of badge with the name of the } \\
\text { employee) }\end{array}$ & VAR00001 & 0.707 & 0.966 \\
\hline 2. & $\begin{array}{l}\text { Availability of informational handouts concerning the main ser- } \\
\text { vices provided by the company }\end{array}$ & VAR00002 & 0.683 & 0.966 \\
\hline 3. & $\begin{array}{l}\text { The personnel perform obligations to customers accurately and } \\
\text { reliably }\end{array}$ & VAR00003 & 0.836 & 0.963 \\
\hline 4. & $\begin{array}{l}\text { Timely fulfillment of obligations by the personnel of the company } \\
\text { to the customer }\end{array}$ & VAR00004 & 0.829 & 0.964 \\
\hline 5. & $\begin{array}{l}\text { The staff of the branch is open to solving customer problems and is } \\
\text { also interested in this }\end{array}$ & VAR00005 & 0.880 & 0.963 \\
\hline 6. & $\begin{array}{l}\text { Initiative of the company's staff (offering related services that may } \\
\text { be useful for a particular customer) }\end{array}$ & VAR00006 & 0.683 & 0.966 \\
\hline 7. & Reliable company reputation & VAR00007 & 0.820 & 0.964 \\
\hline 8. & $\begin{array}{l}\text { Customers do not need to wait for a specific service for a long time } \\
\text { due to queues, etc. }\end{array}$ & VAR00008 & 0.763 & 0.965 \\
\hline 9. & Polite attitude of the personnel towards the customers, goodwill & VAR00009 & 0.851 & 0.963 \\
\hline 10. & $\begin{array}{l}\text { High level of knowledge about the range of services, features of } \\
\text { their provision (staff is always able to answer customer's questions) }\end{array}$ & VAR00010 & 0.849 & 0.964 \\
\hline 11. & Individual approach on the part of the staff of the company & VAR00011 & 0.874 & 0.963 \\
\hline 12. & The priority of the personnel is the customer's interests & VAR00012 & 0.838 & 0.964 \\
\hline 13. & Readiness of the staff to correct mistakes before the customer & VAR00013 & 0.889 & 0.963 \\
\hline 14. & $\begin{array}{l}\text { Availability of an effective feedback system for appeals, com- } \\
\text { plaints and suggestions }\end{array}$ & VAR00014 & 0.745 & 0.965 \\
\hline 15. & $\begin{array}{l}\text { Atmosphere in the company (pleasant design, cleanliness, silence } \\
\text { in the office) }\end{array}$ & VAR00015 & 0.782 & 0.965 \\
\hline
\end{tabular}


Let's calculate the Cronbach's Alpha value for each of the above groups separately and also determine the level of this coefficient when removing each individual sample criterion (Table 3) using the SPSS software.

Table 3. Results of testing the internal consistency of the criteria for evaluating the quality of customer service by groups based on the calculation of Cronbach's Alpha

\begin{tabular}{|c|c|c|c|c|}
\hline No. & Group & $\begin{array}{l}\text { The criterion for evaluating the quality of service of the } \\
\text { branch bank }\end{array}$ & $\begin{array}{l}\text { The value of } \\
\text { Cronbach's } \\
\text { Alpha when } \\
\text { removing the } \\
\text { criterion from } \\
\text { the sample }\end{array}$ & $\begin{array}{l}\text { Cronbach's } \\
\text { Alpha }\end{array}$ \\
\hline \multirow{3}{*}{1.} & \multirow{3}{*}{$\begin{array}{l}\text { Organizational envi- } \\
\text { ronment }\end{array}$} & Appearance of the employees & 0.751 & \multirow{3}{*}{0.791} \\
\hline & & $\begin{array}{l}\text { Availability of informational handouts concerning the } \\
\text { main services provided by the company }\end{array}$ & 0.716 & \\
\hline & & Atmosphere in the company & 0.682 & \\
\hline \multirow{3}{*}{2.} & \multirow{3}{*}{ Reliability } & Reliable company reputation & 0.836 & \multirow{3}{*}{0.861} \\
\hline & & $\begin{array}{l}\text { The personnel perform obligations to customers accu- } \\
\text { rately and reliably }\end{array}$ & 0.747 & \\
\hline & & $\begin{array}{l}\text { Availability of an effective feedback system for appeals, } \\
\text { complaints and suggestions }\end{array}$ & 0.826 & \\
\hline \multirow{3}{*}{3.} & \multirow{3}{*}{ Staff reactivity } & $\begin{array}{l}\text { Timely fulfillment of obligations by the personnel of the } \\
\text { company to the customer }\end{array}$ & 0.687 & \multirow{3}{*}{0.803} \\
\hline & & Initiative of the company's staff & 0.800 & \\
\hline & & $\begin{array}{l}\text { Customers do not need to wait for a specific service for a } \\
\text { long time due to queues, etc. }\end{array}$ & 0.698 & \\
\hline \multirow{3}{*}{4.} & \multirow{3}{*}{$\begin{array}{l}\text { Competence of the } \\
\text { staff }\end{array}$} & $\begin{array}{l}\text { High level of knowledge about the range of services, } \\
\text { features of their provision }\end{array}$ & 0.844 & \multirow{3}{*}{0.890} \\
\hline & & The priority of the personnel is the customer's interests & 0.848 & \\
\hline & & $\begin{array}{l}\text { The staff of the branch is open to solving customer prob- } \\
\text { lems and is also interested in this }\end{array}$ & 0.836 & \\
\hline \multirow{3}{*}{5.} & \multirow{3}{*}{ Empathy of the staff } & $\begin{array}{l}\text { Polite attitude of the personnel towards the customers, } \\
\text { goodwill }\end{array}$ & 0.899 & \multirow{3}{*}{0.919} \\
\hline & & $\begin{array}{l}\text { Individual approach on the part of the staff of the com- } \\
\text { pany }\end{array}$ & 0.866 & \\
\hline & & $\begin{array}{l}\text { Readiness of the staff to correct mistakes before the } \\
\text { customer }\end{array}$ & 0.886 & \\
\hline
\end{tabular}

This will allow to identify those factors that are not meaningful to customers and, accordingly, to reduce the number of criteria.

The results of calculations, presented in Table 3, confirm the high level of consistency of the selected criteria when dividing them into groups.

Besides, the value of Cronbach's Alpha when removing individual sample criteria also indicates that there is no need to exclude any of the selected indicators from the list.

Stage 2. Conducting factor analysis based on the method of the main components. So, after that, only the criteria of analysis which factor values exceed the value of 0.5 should be left in the sample.

The method of the main components allows to exclude from the sample of factors those that do not significantly affect the resultant indicator. All requirements for conducting factor analysis for the analyzed sample are followed, in particular:

1) All criteria are quantitative;

2) The number of observations exceeds the number of criteria more than twice (in this case -10.7 times);

3) Output data are symmetric;

4) The sample is homogeneous;

5) Analysis is carried out by correlative variables (Shumetov et al., 1999).

Calculations were carried out using the Prynpinal component analysis module of the SPSS programme (Table 4).

The calculated Kaiser-Meyer-Olkin (KMO) selective adequacy degree confirms that it makes sense to conduct factor analysis, since the value of the coefficient exceeds 0.5 (Ivanov, 2015) and is 0.960.

Analysis of the results of the "Organizational environment" block indicates that the highest level of importance for the group was the "Atmosphere in the company" indicator, which includes such characteristics as pleasant design, cleanliness, silence in the office. 
Table 4. Results of factor analysis according to the criteria for evaluating the quality of customer service

\begin{tabular}{|c|c|c|c|}
\hline No. & Group & The criterion for evaluating the quality of service of the branch bank & Factor loadings \\
\hline \multirow{3}{*}{1.} & \multirow{3}{*}{$\begin{array}{l}\text { Organizational envi- } \\
\text { ronment }\end{array}$} & Appearance of the employees & 0.553 \\
\hline & & $\begin{array}{l}\text { Availability of informational handouts concerning the main services provid- } \\
\text { ed by the company }\end{array}$ & 0.513 \\
\hline & & Atmosphere in the company & 0.662 \\
\hline \multirow{3}{*}{2.} & \multirow{3}{*}{ Reliability } & Reliable company reputation & 0.719 \\
\hline & & The personnel perform obligations to customers accurately and reliably & 0.737 \\
\hline & & The personnel perform obligations to customers accurately and reliably & 0.604 \\
\hline \multirow{3}{*}{3.} & \multirow{3}{*}{ Staff reactivity } & $\begin{array}{l}\text { Timely fulfillment of obligations by the personnel of the company to the } \\
\text { customer }\end{array}$ & 0.728 \\
\hline & & Initiative of the company's staff & 0.514 \\
\hline & & $\begin{array}{l}\text { Customers do not need to wait for a specific service for a long time due to } \\
\text { queues, etc. }\end{array}$ & 0.633 \\
\hline \multirow{3}{*}{4.} & \multirow{3}{*}{$\begin{array}{l}\text { Competence of the } \\
\text { staff }\end{array}$} & $\begin{array}{l}\text { High level of knowledge about the range of services, features of their provi- } \\
\text { sion }\end{array}$ & 0.765 \\
\hline & & The priority of the personnel is the customer's interests & 0.746 \\
\hline & & $\begin{array}{l}\text { The staff of the branch is open to solving customer problems and is also } \\
\text { interested in this }\end{array}$ & 0.809 \\
\hline \multirow{3}{*}{5.} & \multirow{3}{*}{ Empathy of the staff } & Polite attitude of the personnel towards the customers, goodwill & 0.770 \\
\hline & & Individual approach on the part of the staff of the company & 0.804 \\
\hline & & Readiness of the staff to correct mistakes before the customer & 0.825 \\
\hline
\end{tabular}

According to the "Reliability" group, the company's reputation and the accuracy and reliability of performing the obligations to customers criteria are predominant among the totally high indicators $-71.9 \%$ and $73.7 \%$, respectively.

Timeliness of fulfillment of obligations by the personnel to the customer $(72.8 \%)$ was determined by respondents as an important factor among the criteria of the block "Stuff reactivity". Moreover, in this group, the lowest importance is obtained by the criterion "Initiative of the company's staff", which indicates that the relation to this factor among customers is twofold. Accordingly, the staff should take into account the individual characteristics of customers.

The criteria assigned to the group "Competence of the staff" were highly valued by customers. Especially distinguished factor is "The staff of the branch is open to solving customer problems and is also interested in this" which factor loading was $80.9 \%$.

Having analyzed the group of criteria "Empathy of the staff" one can state that they received high ratings of importance, in particular, the availability of an individual approach on the part of the staff of the company to the customer, as well as the readiness of the staff to correct mistakes before the customer.

Figure 2 is a graphical illustration of the principal component method.

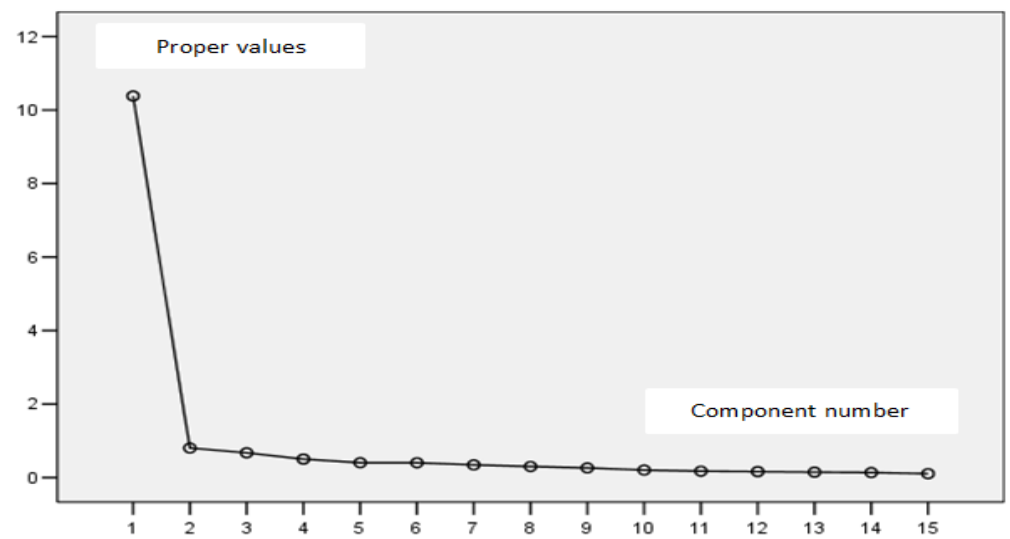

Figure 2. Graphic criterion of scree plot 
As a rule, according to the results of factor analysis, a combination of criteria excludes those with a low level of factor loading (less than 0.5). As shown in the Table 4 according to the results of calculations, all criteria chosen by us are significant and consequently all 15 characteristics of customer service quality should be left for further analysis. Factor loadings characterize the degree of interrelation of the relevant criteria and the overall assessment: the greater the absolute value of the factor loading, the stronger is the connection of the resulting indicator with the component under study and consequently the greater its contribution and especially the overall assessment of the quality of service due to the action of the relevant criterion. The factor loadings obtained by the method of the principal components are used as weight coefficients for each of the factors of customer service quality evaluation.

Stage 3. Estimation of the internal consistency of the criteria for evaluating the quality of customer service remaining after factor analysis, based on the calculation of the Cronbach's $\alpha$ coefficient. Since all the evaluation criteria were significant at the previous stage, it is not necessary to recalculate Cronbach's Alpha within the study.

Stage 4. Calculation of the aggregative coefficient of the received quality service ratings according to the selected criteria.

On the basis of the data obtained from the questionnaire, we will calculate the integral assessment of the level of customer service quality in each of the three study branches of the bank by the formula:

$\mathrm{Q}_{\mathrm{i}}=\sum_{\mathrm{i}=1}^{\mathrm{j}} \frac{\sum_{\mathrm{i}=1}^{\mathrm{n}} \mathrm{P}_{\mathrm{ij}} * \mathrm{~W}_{\mathrm{j}}}{\mathrm{n}_{\mathrm{i}}}$

where:

$Q_{i}$ - integral assessment of the level of the customer service quality in the bank's branch; $P_{i j}$ - estimation by the client of the j-th criterion of the service quality of the i-th branch of the bank; $W_{j}$ - weighting coefficient of the criterion of the service quality of $j$-th criterion; $n_{i}-$ number of respondents in the $i$-th branch of the bank.

Table 5 shows the results of calculations made for branches of PJSC CB "PrivatBank".

Table 5. Integral assessment of the level of quality of customer service of the investigated branches of PJSC CB "PrivatBank"

\begin{tabular}{|c|l|c|c|c|}
\hline No. & \multicolumn{1}{|c|}{ Indicator } & Branch I & Branch II & Branch III \\
\hline 1. & VAR00001 & 3.31 & 3.38 & 3.65 \\
\hline 2. & VAR00002 & 3.00 & 2.88 & 3.11 \\
\hline 3. & VAR00003 & 4.13 & 4.08 & 4.91 \\
\hline 4. & VAR00004 & 4.09 & 4.02 & 4.88 \\
\hline 5. & VAR00005 & 4.68 & 4.48 & 5.42 \\
\hline 6. & VAR00006 & 2.95 & 2.96 & 3.08 \\
\hline 7. & VAR00007 & 4.18 & 3.94 & 4.77 \\
\hline 8. & VAR00008 & 3.39 & 3.47 & 5.07 \\
\hline 9. & VAR00009 & 4.57 & 4.67 & 5.15 \\
\hline 10. & VAR00010 & 4.59 & 4.61 & 5.33 \\
\hline 11. & VAR00011 & 4.74 & 4.68 & 5.04 \\
\hline 12. & VAR00012 & 4.40 & 4.22 & 5.60 \\
\hline 13. & VAR00013 & 4.82 & 4.54 & 3.86 \\
\hline 14. & VAR00014 & 3.41 & 3.14 & 4.30 \\
\hline 15. & VAR00015 & 4.09 & 3.95 & 68.43 \\
\hline Resultative indicator of the service quality & 60.35 & 59.01 & \\
\hline
\end{tabular}

\section{Conclusions}

The system of criteria has been developed to calculate the integral level of customer service quality. Practical calculations were made based on customer surveys of three branches of PJSC CB "PrivatBank", where respondents indicated the degree of importance of each criterion for them and the extent of compliance with this criterion in the investigated branch (by Likert scale from 1 to 7 points). Data representativeness is confirmed by compliance with the requirements for the ratio of respondents number to the evaluation criteria (according to the method Nunally and Bernstein) and the results of the evaluation of internal consistency of criteria (Cronbach's $\alpha$ indicator for the entire set of criteria was 0.967 , and its values obtained by stepwise removal of each criterion in the sample exceeded 0.7; the calculations were carried out using the software package SPSS - Statistical package for the Social Sciences). In order to avoid sampling of those criteria do not significantly affect the resulting figure the 
principal components method was used (calculations - using the module of Principal component analysis of the package SPSS). Representativeness of the criteria set confirms the value of the Kaiser-Meyer-Olkin sampling adequacy index at 0.960 .

This allowed to form such a system of customer service quality criteria (in parentheses we indicated factor loadings calculated by the method of principal components): 1) organizational environment indicators: appearance of staff $(0.553)$; availability of information materials about the company $(0.513)$; atmosphere in the company $(0.662)$; 2) reliability indicators: company reputation $(0.719)$; level of fulfillment of obligations to customers (0.737); effectiveness of the feedback system for complaints and suggestions (0.604); 3) indicators of stuff reactivity: timeliness of fulfillment of obligations to the customer (0.728); initiative of the staff (0.514); absence of queues (0.633); 4) indicators of competence of the stuff: level of knowledge about the features of the company and services (0.765); priority of customer's interests (0.746); openness and interest of the personnel in solving customer problems $(0.809) ; 5)$ indicators of empathy of the staff: polite attitude towards the customer (0.770); individual approach to the customer (0.804); readiness of the staff to correct mistakes before the customer $(0.825)$.

\section{References}

1. Carlo, Gabriel Porto Bellini and Rita, de Cássia de Faria Pereira (2008). Service Quality in Banks: What are the Factors Behind Performance and Customer Satisfaction? Advances in Banking Technology and Management: Impacts of ICT and CRM, 16-32.

2. Carol, Lu, Celine, Berchoux, Michael, W. Marek, Brendan Chen (2015). Service quality and customer satisfaction: qualitative research implications for luxury hotels. International Journal of Culture, Tourism and Hospitality Research, 9(2), 168-182. Available at: https://doi.org/10.1108/IJCTHR-10-2014-0087.

3. David, Ackah (2014). Services Quality and Customer Satisfaction in the Banking Industries. Available at: https://www.linkedin.com/pulse/20141014164938-198507110-services-quality-and-customer-satisfaction-inthe-banking-industries.

4. Funtowicz, S. O. and Ravetz, J. R. (1990). Uncertainty and quality in science for policy. Kluwer Academic Publishers, Dordrecht, Netherlands.

5. George, D., \& Mallery, P. (2003). SPSS for Windows step by step: A simple guide and reference. 11.0 update (4th ed.). Boston: Allyn \& Bacon.

6. Hayat, Muhammad Awan, Khuram, Shahzad Bukhari, Anam, Iqbal (2011). Service quality and customer satisfaction in the banking sector: A comparative study of conventional and Islamic banks in Pakistan. Journal of Islamic Marketing, 2(3), 203-224. Available at: https://doi.org/10.1108/17590831111164750.

7. Huseyin, Arasli, Salih, Turan Katircioglu, Salime, Mehtap-Smadi, (2005). A comparison of service quality in the banking industry: Some evidence from Turkish- and Greek-speaking areas in Cyprus. International Journal of Bank Marketing, 23(7), 508-526. Available at: https://doi.org/10.1108/02652320510629881.

8. I-Ming, Wang \& Chich-Jen Shieh (2006). The relationship between service quality and customer satisfaction: the example of CJCU library. Journal of Information and Optimization Sciences, 27(1), 193-209.

9. Ivanov, O. V. (2015). Kurs "Prikladnaia statistika" [Course "Applied Statistics"] [Electronic resource]. Training courses. - Available at: http://msu-students.ru/stat.html.

10.Ngo, Vu Minh, Nguyen, Huan Huu (2016). The Relationship between Service Quality, Customer Satisfaction and Customer Loyalty: An Investigation in Vietnamese Retail Banking Sector. Journal of Competitiveness, 8(2), 103-116. doi: 10.7441/joc.2016.02.08.

11.Osman, M. Karatepe, Ugur, Yavasb, Emin, Babakusc (2005). Measuring service quality of banks: Scale development and validation. Journal of Retailing and Consumer Services, 12(5), 373-383. Available at: https://doi.org/10.1016/j.jretconser.2005.01.001.

12.Parasuraman, A. (1988). SERVQUAL: A Multiple-Item Scale for Measuring Consumer Perceptions of Service Quality / A. Parasuraman, V. A. Zeithaml, L. L. Berry. Journal of Retailing, 64(1), 12-37.

13. Rubogora Felix (2017). Service Quality and Customer Satisfaction in Selected Banks in Rwanda. Journal of Business \& Financial Affairs, 6(1), DOI: 10.4172/2167-0234.1000246.

14. Shumetov, V. H., Shumetova, L. V. (1999). Faktornyi analiz: podkhod s primeneniiem EVM [Factor analysis: an approach with the use of a computer]. OrelHTU, Orel. $88 \mathrm{p}$.

15. Smith, S. (1998). How to create a plan to deliver great customer service. In Zemke, R. \& Woods, J. A. (Eds.). Best Practices in Customer Service. New York, NY: AMACOM. 
16. Sureshchandar, G.S., Chandrasekharan Rajendran, Anantharaman, R.N. (2002). The relationship between service quality and customer satisfaction - a factor specific approach. Journal of Services Marketing, 16(4), 363-379. Available at: https://doi.org/10.1108/08876040210433248.

17.Titko, J. (2013). Service quality in banking: developing and testing measurement instrument with Latvian sample data / J. Titko, N. Lace, K. Kozlovskis // Acta Universitatis Agriculturae et Silviculturae Mendelianae Brunensis, LXI(2), 507-515.

18. Van Iwaarden, J., van der Wiele, T., Ball, L. \& Millen, R. (2003). Applying SERVQUAL to Web sites: An exploratory study. International Journal of Quality and Reliability Management, 20(8), 919-935. Available at: http://dx.doi.org/10.1108/02656710310493634.

19. Wernerfelt, B. (1991). Brand loyalty and market equilibrium. Marketing Science, 10(3), 229-245. Available at: http://dx.doi.org/10.1287/mksc.10.3.229.

20. Yee, R. W. Y., Yeung, A. C. L. \& Cheng, T. C. E. (2010). An empirical study of employee loyalty, service quality and firm performance in the service industry. International Journal of Production Economics, 124(1), 109-120. Available at: http://dx.doi.org/10.1016/j.ijpe.2009.10.015.

\section{Appendix A. Questionnaire layout to conduct a survey on customer service quality}

Dear customers!

We ask you to familiarize yourself with the questions of the questionnaire and to evaluate the importance of each of the criteria for service.

This questionnaire will enable us to understand your wishes, implement them and improve the quality of our customers' service.

\section{According to each criterion You are asked to answer two questions:}

1) Describe Your expectations about the quality of service as a whole: how important is this characteristics personally for You?

2) Describe the actual quality of service in this company: what level of service quality according to this criterion in this company?

Please, give Your estimate according to the scale from 1 to 7 points:

Fully Fully

disagree agree

\begin{tabular}{|c|c|c|c|}
\hline & 4 & & \\
\hline No. & Criterion for evaluating the quality of service of the branch bank & $\begin{array}{l}\text { Importance of the } \\
\text { criterion for you } \\
\text { (from } 1 \text { to } 7 \text { ) }\end{array}$ & $\begin{array}{l}\text { Evaluation of this } \\
\text { branch by criterion } \\
\text { (from } 1 \text { to } 7 \text { ) }\end{array}$ \\
\hline 1. & $\begin{array}{l}\text { Appearance of employees (cleanliness, pleasant appearance, business } \\
\text { dress code, availability of badge with the name of the employee) }\end{array}$ & & \\
\hline 2. & $\begin{array}{l}\text { Availability of informational handouts concerning the main services } \\
\text { provided by the company }\end{array}$ & & \\
\hline 3. & The personnel perform obligations to You accurately and reliably & & \\
\hline 4. & Timely fulfillment of obligations by the personnel of the company to You & & \\
\hline 5. & $\begin{array}{l}\text { The staff of the branch is open to solving Your problems and is also } \\
\text { interested in this }\end{array}$ & & \\
\hline 6. & $\begin{array}{l}\text { Initiative of the company's staff (offering related services that may be } \\
\text { useful for You) }\end{array}$ & & \\
\hline 7. & Reliable company reputation & & \\
\hline 8. & $\begin{array}{l}\text { You do not need to wait for a specific service for a long time due to } \\
\text { queues, etc. }\end{array}$ & & \\
\hline 9. & Polite attitude of the personnel to You, goodwill & & \\
\hline 10. & $\begin{array}{l}\text { High level of knowledge about the range of services, features of their } \\
\text { provision (staff is always able to answer customer's questions) }\end{array}$ & & \\
\hline 11. & Individual approach on the part of the staff of the company & & \\
\hline 12. & The priority of the personnel is the customer's interests & & \\
\hline 13. & Readiness of the staff to correct mistakes before the customer & & \\
\hline 14. & $\begin{array}{l}\text { Availability of an effective feedback system for appeals, complaints } \\
\text { and suggestions }\end{array}$ & & \\
\hline 15. & $\begin{array}{l}\text { Atmosphere in the company (pleasant design, cleanliness, silence in the } \\
\text { office) }\end{array}$ & & \\
\hline
\end{tabular}

